\title{
Analysis of the Tropism and Anti-Bacterial Potential of a Type of Clay
}

\author{
Cássio Ilan Soares Medeiros ${ }^{1 *}$, Erica Renata Nogueira Sá ${ }^{1}$, Juliana Raquel de Morais Santos \\ Oliveira $^{2}$, Lis Magalhães ${ }^{3}$, Geraldo Gonçalves de Almeida Filho" ${ }^{4}$, \\ Hilzeth de Luna Freire Pessôa ${ }^{4}$ \\ ${ }^{1}$ Graduate Student in Biomedicine, Integrated College of Patos, Paraíba, Brazil \\ ${ }^{2}$ ICU Specialist Physiotherapist, Integrated College of Patos, Paraíba, Brazil \\ ${ }^{3}$ Medical Student, College of Santa Maria, Cajazeiras Paraíba, Brazil \\ ${ }^{4} \mathrm{MSc}$. in Natural and Synthetic Bioactive Products, Federal University of Paraíba, UFPB, João Pessoa, Brazil \\ Email: ${ }^{*}$ cassioism@hotmail.com
}

Received 20 April 2014; revised 20 May 2014; accepted 20 June 2014

Copyright (C) 2014 by authors and Scientific Research Publishing Inc.

This work is licensed under the Creative Commons Attribution International License (CC BY).

http://creativecommons.org/licenses/by/4.0/

(c) (i) Open Access

\begin{abstract}
Natural clays have been used by man in infections of bacterial etiology, since the first historical registers. Our attention turned to a red-colored clay, known in the northeast of Brazil as "barro de louça" (dish clay). These clays and other natural earth materials seem interesting to us, as the blockage of the liberation of toxins or inactivation, may be related to the interruption of infection cycles in the skin and mucous membranes. The adsorptive and absorptive properties of the mineral clays are well documented in the cure process of skin and gastrointestinal diseases. Susceptibility and bacterial tropism tests were carried out. The results were analyzed and interpreted according to the conventional microbiological protocol. The bacterial strains, Staphylococcus aureus, Escherichia coli e Pseudomonas aeruginosa, did not present a susceptibility profile to an isotonic solution of clay, but there was an increase of the bacterial tropism as the concentration of the isotonic solution was increased, being the minimal observed concentration of $100 \mathrm{mg} / \mathrm{mL}$. Our aim is to document a type of red clay from the northeast of Brazil with possible attraction properties (Tropism) to bacteria and their toxins.
\end{abstract}

\section{Keywords}

Red Clay, Bacterial Tropism, Bacterial Resistance

\section{Introduction}

The practices of ancient cultures such as the indigenous people, as well as the modern society have depended on

"Corresponding author.

How to cite this paper: Medeiros, C.I.S., Sá, E.R.N., de Morais Santos Oliveira, J.R., Magalhães, L., de Almeida Filho, G.G. and de Luna Freire Pessôa, H. (2014) Analysis of the Tropism and Anti-Bacterial Potential of a Type of Clay. Open Journal of Medical Microbiology, 4, 140-145. http://dx.doi.org/10.4236/ojmm.2014.42016 
the mineral present in the clays, as these are powerful adsorber. The absorption properties for the treatment of a variety of topic diseases are also important. The adsorption is the process of attraction, bonding and building-up of particles or molecules to a solid surface. The absorption occurs when a substance permeates or penetrates a liquid or solid forming a transition zone [1]-[3].

The clay minerals are ubiquitous in nature and their absorption and adsorption capacity has been explored in a variety of cosmetic and pharmaceutical formulations. Traditionally, the clay minerals are mixed with water to form clay pastes that may be applied externally for cosmetic purposes or for the skin's protection [4].

The high capacity for adsorption and absorption, cations exchange, as well as the granulometry of extremely thin particles of some clays, containing, for instance, the smectite clay (expandable clay minerals) and minerals of the kaolin group are important reasons why these minerals are used to remove skin oils, secretions, toxins and contaminants. By the adsorption and absorption of the humidity and impurities, the clays can also be used to cleanse and refresh the skin's surface and help in the healing processes [5]-[7].

Due to the evolution and dissemination of antimicrobial resistance as a result of excessive and indiscriminate use of antibiotic agents in the healthcare area, the study of clays with antibacterial properties may provide us with alternative mechanisms for this problem [8]-[10]. French green clays were documented due to their efficiency in the treatment of Buruli ulcer, a necrotizing fasciitis caused by Mycobacterium ulcerans, in addition, they demonstrated efficiency when facing the bacteria Escherichia coli, Staphylococcus aureus, Pseudomonas aeruginosa, antibiotic resistant extended-spectrum beta lactamase (ESBL) E. coli e methicillin resistant S. aureus (MRSA) [11] [12]. Consequently, our aim is to document a type of red clay from the northeast of Brazil with possible attraction properties (Tropism) to bacteria and their toxins.

\section{Materials and Methods}

\subsection{Preparation of Clay Material}

The argillaceous material was submitted to maceration and screening, and after that, diluted in physiological solution $0.9 \%$ and two isotonic clay solutions were obtained at $100 \mathrm{mg} / \mathrm{mL}$ and one of the samples was sterilized in autoclave at $121^{\circ} \mathrm{C}$ for 20 min before the microbial tests to remove any environmental bacteria which may have adhered to the mineral's surfaces.

\subsection{Preparing and Use of Bacterial Strains}

The anti-bacterial properties and tropism of the used red clay were assessed using conventional microbiological protocols, using strains obtained from the American Type Culture Collection (ATCC). The initial cultures of Staphylococcus aureus 25,213 and 25,925, Pseudomonas aeruginosa 25,619, Escherichia coli 10,536, 8859 end Bacillus subtilis 0516 were cultivated during $24 \mathrm{~h}$ and diluted in Brain Heart Infusion (BHI) broth culture medium for an approximate density of $5 \times 10^{6} \mathrm{CFU} / \mathrm{mL}$ (CFU: colony forming units).

\subsection{Susceptibility Bacterial Tests}

To confirm the initial bacterial counts, serially diluted cultures were plated on adequate agar and numbered. After dilution, approximately $60 \mathrm{mg}$ of sterilized clay minerals were mixed with $540 \mu \mathrm{L}$ of a medium containing the initial bacterial strain to reach a consistence similar to the one of the hydrated clay plasters used. The mixtures of bacteria and mineral were incubated during 24 hours at $37^{\circ} \mathrm{C}$ in a bacteriological incubator with adapted homogenizer. The positive controls for the growth of the bacteria in the absence of clay minerals were included in each series of independent experiments. After the incubation, the mixtures were submitted to successive serially dilutions and posteriorly were plated in agar to determine the number of viable bacteria. Furthermore, about $100 \mu \mathrm{L}$ of bacteria with clay suspension was prepared directly on agar dishes to evaluate the viability of the bacteria in non-diluted samples. All the antimicrobial tests with specific argillaceous minerals were carried out in triplicate [13].

\subsection{Test Bacterial Tropism}

The test for the bacterial tropism were carried out with samples of non-sterile clay, however free of contaminating micro-organisms which were confirmed by inoculating plasters clay in sterile agar, and diluted in physio- 
logical solution $0 \%, 9 \%$ and $100 \% \mathrm{mg} / \mathrm{mL}$. The bacterial suspensions were obtained by means of inoculation in liquid enrichment broth BHI, and after incubated at $37^{\circ} \mathrm{C}$ for $24 \mathrm{~h}$. After this period, the bacterial growth was observed by the means of the turbidity of the samples and the inoculated in agar. Around $100 \mu \mathrm{L}$ of the bacterial strains were inoculated in Mueller-Hinton $(\mathrm{MH})$ agar, and using a Drigalky strap the plating, using the Spread Plate technique, was carried out. The sterile filter paper discs of $5 \mathrm{~mm}$ diameter were positioned in the surface of the medium, and deposited around $50 \mu \mathrm{L}$ of the isotonic clay solution. Hydrated clay plasters were prepared and positioned in agar. The plates were incubated at $37^{\circ} \mathrm{C}$ and were analyzed after $24 \mathrm{~h}$ [14]-[16].

\section{Results and Discussion}

The most important physical-chemical factors for impeding the bacterial viability are the temperature, the $\mathrm{pH}$, osmotic pressure, oxidation state, and the concentration of nutrients and residues. The internal stability of the bacterial cells depends on the interaction between a series of physiological factors, and the disturbance of this stability through mechanisms which impede the nutrition, interrupting essential metabolic activities, suffocation (making the cellular wall impermeable), poisoning (a toxin delivery) or physical rupture (cell lysis by bursting or penetration) may determine the bacteria's death or the inhibition of its growth [17].

In the bacterial susceptibility tests were observed a viability constancy of $5 \times 10^{6} \mathrm{CFU} / \mathrm{mL}$ obtained from the initial dilutions, the results showed that even in the presence of the clay minerals the bacterial strains continue viable and maintain the dilution density when plated in agar, based on the data spectrophotometry.

When the bacterial tropism tests were carried out, it was possible to observe an increase in the agar's transparency, and the possible decrease of the microbial colonies' density, except for the strains of Escherichia coli 8859 end Bacillus subtilis 0516 that shows growing across plaque (Figure 1 and Figure 2). However, it seems that there was an increase in the density of the bacterial toxins and the colonies or both around the hydrated clay plasters applied in the center of the plate over the sterile paper filter discs. This phenomenon seems to demonstrate the isomorphic substitution activity in the tetrahedral and octahedral positions in the crystalline structure of the clay minerals when humidified, besides the possible electrodynamics interactions of the organic molecules or colloids in the clay minerals [7] [18] [19] (Figures 3-6).

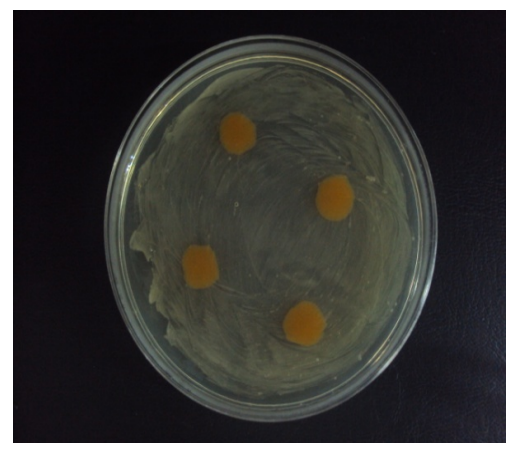

Figure 1. E. coli 8859.

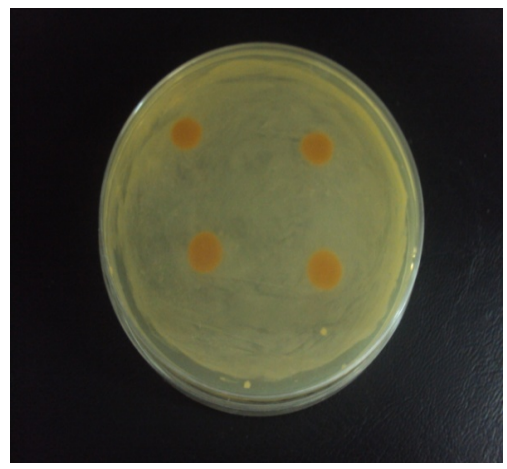

Figure 2. B. subtilis 0516. 


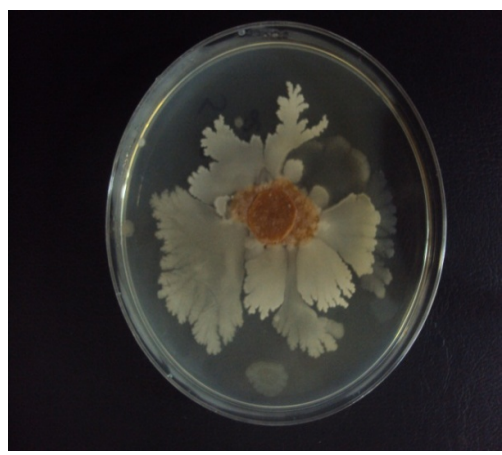

Figure 3. S. aureus 25213.

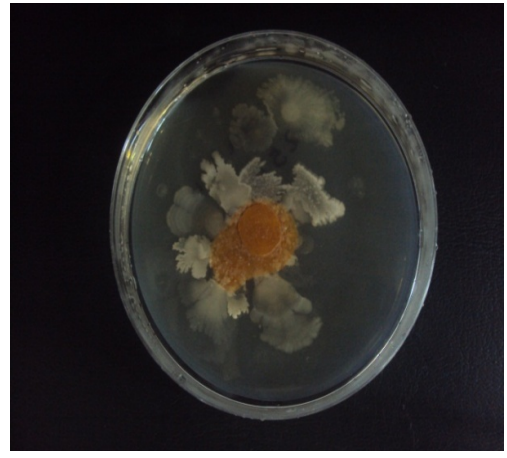

Figure 4. S. aureus 25925.

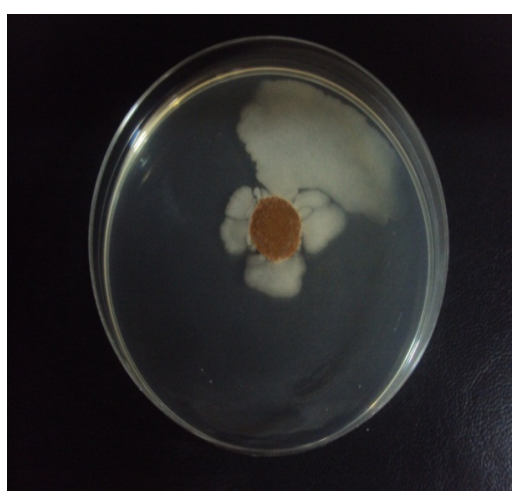

Figure 5. P. aeruginosa 25619.

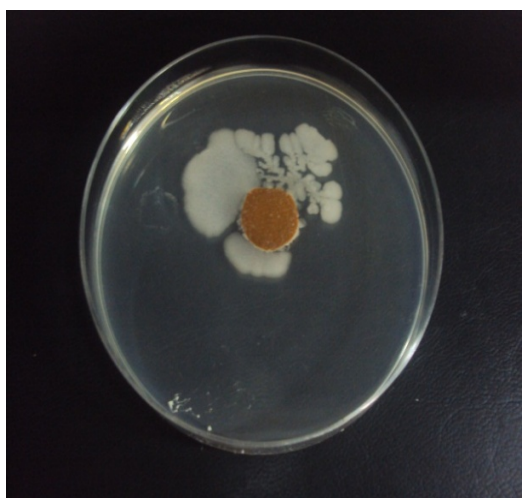

Figure 6. E. coli 10536. 
When there is breaking of the chemical bonds of the edges of the mineral clays, together with the interaction of the ions $\mathrm{H}_{3} \mathrm{O}^{+}$, there possibly is the formation of electrical charges of negative polarity in the surface of the structural units and the colloids [18] [20]. The bacterial endo and exotoxins have a general electrical charge of positive polarity [20] [21]. The elevated adsorption and absorption capacity, cations exchange capacity which are involved in the interaction processes of the bacterial toxins and the clay minerals, show us that the greater the cationic activity is, the higher the interaction, (absorption of toxins and free radicals from the surfaces which they come into contact with) will be [7].

When the hydrated clay plasters were submitted to dilutions, it seems that there was a decrease in the electrodynamic attraction in the interface (mineral-bacteria). Where the lowest concentration with the possibility of visualization were of $100 \mathrm{mg} / \mathrm{mL}$.

\section{Conclusions}

The natural Earth material (red clay) proved to be inefficient, as a bactericidal and bacteriostatic agent, as the bacterial strains; Staphylococcus aureus 25,213 and 25,925, Pseudomonas aeruginosa 25,619 and Escherichia coli 10,536 did not present an anti-argillaceous susceptibility profile. The clay plasters hydrated on agar demonstrated a high capacity of attraction (bacterial tropism) when non-sterile minerals are used, suggesting that the treatment by autoclave may be the factor responsible for the denaturation, mainly of the organic or colloidal molecules.

It is always necessary to seek new ways and measures for solving the problems of everyday life, thus more specific to a better understanding of bacterial tropism of the studied clay studies are needed. However, we can state that the probable adsorption capacity and absorption of toxins and free radicals that have red clay may become an important tool in combating infectious inflammatory diseases.

\section{Acknowledgements}

Sincere gratitude to the Cellular and Molecular Biology Department of the Federal University of Paraíba (MBD), UFPB, on behalf of the professor $\mathrm{Dr}^{\mathrm{a}}$. Hilzeth de Luna Freire Pessôa, and to the Microbiology Research Laboratory of the Integrated College of Patos, Paraíba MRL, FIP-PB.

\section{References}

[1] Williams, L.B., Holland, M., Eberl, D.D., Brunet, T. and Brunet de Courssou, L. (2004) Killer Clays! Natural Antibacterial Clay Minerals. Mineral Society Bulletin, London, 139, 3-8.

http://www.ncbi.nlm.nih.gov/pmc/articles/PMC3126108

[2] Carretero, M.I. and Lagaly, G. (2007) Clays and Health: An Introduction. Applied Clay Science, 36, 1-3. http://www.ncbi.nlm.nih.gov/pmc/articles/PMC2895274 http://dx.doi.org/10.1016/j.clay.2006.09.001

[3] Zague, V., Santos, D.A., Baby, A.R. and Velasco, M.V.R. (2007) Argilas: Natureza das máscaras faciais. Cosmetics \& Toiletries, 19, 64.

[4] Gomes, C.S.F. and Silva, J.B.P. (2007) Minerals and Clay Minerals in Medical Geology. Applied Clay Science, 36, 421. http://dx.doi.org/10.1016/j.clay.2006.08.006

[5] Amorim, L.V., Viana, J.D., Farias, K.V., Barbosa, M.I.R. and Ferreira, H.C. (2006) Estudo comparativo entre variedades de argilas bentoníticas de Boa Vista, Paraíba. Revista Matéria, 11, 30-40. http://www.scielo.br/pdf/rmat/v11n1/a06v11n1.pdf

[6] Sozer, N. and Kokini, J.L. (2009) Review: Nanotechnology and Its Applications in the Food Sector. Trends in Biotechnology, 27, 82-89. http://dx.doi.org/10.1016/j.tibtech.2008.10.010

[7] Williams, L.B. and Hayel, S.E. (2010) Evaluation of the Medicinal Use of Clay Minerals as Antibacterial Agents. NIH Public, 52, 745-770.

[8] Fernades, P. (2006) Antibacterial Discovery and Development-The Failure of Success? Nature Biotechnology, 24, 1497-1503. http://dx.doi.org/10.1038/nbt1206-1497

[9] Martinez, J.L. (2009) The Role of Natural Environments in the Evolution of Resistance Traits in Pathogenic Bacteria. Proceedings of the Royal Society B: Biological Sciences, 276, 2521-2530. http://dx.doi.org/10.1098/rspb.2009.0320

[10] Williams, L.B., Metge, D.W., Eberl, D.D., Harvey, R.H., Turner, A.G., Prapaipong, P. and Poret-Peterson, A.T. (2011) 
What Makes a Natural Clay Antibacterial? National Institutes of Health, 45, 3768-3773. http://www.ncbi.nlm.nih.gov/pmc/articles/PMC3126108

[11] Williams, L.B., Haydel, S.E., Geise, R.F., Eberl, D.D. (2008) Chemical and Mineralogical Characteristics of French Green Clays Used for Healing. Clays Clay Minerals, 56, 437-452. http://www.ncbi.nlm.nih.gov/pubmed/19079803

[12] Cunningham, T.B., Koehl, J.L., Summers, J.S. and Haydel, S.E. (2010) pH-Dependent Metal Ion Toxicity Influences of the Antibacterial Activity of Two Natural Mineral Mixtures. http://www.ncbi.nlm.nih.gov/pubmed/20209160

[13] Haydel, S.E., Remineh, C.M. and Williams, L.B. (2008) Broad-Spectrum in Vitro Antibacterial Activities of Clay Minerals against Anti Biotic-Susceptible and Antibiotic-Resistant Bacterial Pathogens. Journal of Antimicrobial Chemotherapy, in Press.

[14] Jackson, M.L. (1979) Soil Chemical Analysis Advanced Course. 2nd Edition.

[15] Tovar-Sanchez, A., Sanudo-Wilhelmy, S.A., Garcia-Vargas, M., Weaver, R.S., Popels, L.C. and Hutchins, D.A. (2003) A Trace Metal Clean Reagent to Remove Surface-Bound Iron from Marine Phytoplankton. Marine Chemistry, 82, 9199. http://dx.doi.org/10.1016/S0304-4203(03)00054-9

[16] Vogel, C. and Fisher, N.S. (2010) Metal Accumulation by Heterotrphic Marine Bacterioplankton. Limnology and Oceanography, 55, 519-528. http://dx.doi.org/10.4319/lo.2009.55.2.0519

[17] Nolte, W.A. (1982) Oral Microbiology. 4. Mosby, London. 3-37. http://www.bibliotecadigital.unicamp.br/document/?down=000788730

[18] Menezes, R.R., Souto, P.M., Santana, L.N.L., Neves, G.A., Kiminami, R.H.G.A. and Ferreira, H.C. (2009) Argilas bentoníticas de Cubati, Paraíba, Brasil: Caracterização físico-mineralógica. Cerâmica, 55, 163-169. http://dx.doi.org/10.1590/S0366-69132009000200008

[19] Beiler, R.C.G. (2012) Kinetic Study of Incorporation of Zinc in Bentonite: Development of Antimicrobial Material. 77F. Dissertation (Postgraduate Program in Chemical Engineering), Federal University of Santa Catarina, Florianópolis.

[20] Silva, M.L.G. (2011) Preparation and Characterization of Piauí paligorsquita clay (attapulgite) organophilizated for Use in Cosmetic formutions. 106f. Dissertation (Postgraduate Diploma in Pharmaceutical Sciences), Federal University of Piauí, Teresina.

[21] Souza, V.M. and Antunes, J.D. (2008) Dermatological Active: Guide Dermatological Assets Used in Pharmacy Compounding for Physicians and Pharmacists. Pharmabooks, Sao Paulo. 